\title{
Integrated Utilization of Guava (Psidium guajava L.): Antioxidant Activity of Phenolic Extracts Obtained from Guava Seeds with Supercritical $\mathrm{CO}_{2}$-Ethanol
}

\author{
Mile A. Hernández-Acosta, Henry I. Castro-Vargas and Fabián Parada-Alfonso* \\ Department of Chemistry, Science Faculty, Universidad Nacional de Colombia, \\ $30^{\text {th }}$ Avenue and $45^{\text {th }}$ St., Bogotá D. C., Colombia
}

\begin{abstract}
Neste trabalho, explorou-se a possibilidade de obter extratos fenólicos com atividade antioxidante (AA) a partir de sementes de goiaba Colombiana (Psidium guajava L.) usando dióxido de carbono supercrítico adicionado com etanol como cosolvente ( $\left.\mathrm{SC} \mathrm{CO}_{2} / \mathrm{EtOH}\right)$. Extratos brutos foram obtidos através de planejamentos de etapas de extração em função da pressão (10, 15 e $20 \mathrm{MPa}$ ) e temperatura (313, 323 e $333 \mathrm{~K}$ ) (com quatro diferentes planejamentos de etapas de extração). Em cada um dos extratos, determinou-se o conteúdo de fenólico total (TPC) e AA (métodos de clareamento do $\beta$-caroteno e DPPH (2,2-difenil-1-picrilhidrazila) de eliminação). Este trabalho permitiu obter um extrato fenólico mais eficaz, com atividade antioxidante mais potente comparada com outros trabalhos. O extrato mais ativo foi fracionado utilizando coluna cromatográfica rápida (FCC), cujo processo foi monitorado por coluna cromatográfica de camada fina (TLC), sendo obtidas quatro frações. A fração mais ativa e o melhor extrato bruto foram testados como antioxidantes de óleos vegetais (as variáveis de resposta foram valor de peróxido (PV) e dieno conjugados (CD)). Observou-se que a fração IV teve um bom desempenho na prevenção da formação de peróxidos, enquanto que o melhor extrato bruto inibiu a degradação de dienos conjugados. Semente de goiaba é uma promissora fonte de antioxidantes que podem ser extraídos usando $\mathrm{SC} \mathrm{CO}_{2} / \mathrm{EtOH}$ a partir de planejamento especial de etapas de extração, estes compostos podem ser utilizados como conservantes em alimentos como óleos.
\end{abstract}

In this work, it was explored the possibility of obtaining phenolic extracts with antioxidant activity (AA) from Colombian guava seeds (Psidium guajava L.) using supercritical carbon dioxide adding ethanol as cosolvent ( $\left.\mathrm{SC} \mathrm{CO}_{2} / \mathrm{EtOH}\right)$. The crude extracts were obtained by block extraction designs step to step (four steps) as function of pressure (10,15 and $20 \mathrm{MPa}$ ) and temperature (313, 323 and $333 \mathrm{~K}$ ) (with four different extraction step designs). In each one of the extracts, the total phenolic content (TPC) and AA were determined ( $\beta$-carotene bleaching and scavenging DPPH (2,2-diphenyl-1-picrylhydrazyl) methods). This work allowed to obtain a most effective phenolic extract, that presented a most potent antioxidant activity compared toward previous works. The most active extract was subjected to flash chromatography column (FCC), whose process was monitored by thin layer chromatography (TLC), being obtained four fractions. The most active fraction and the best crude extract were tested as potential antioxidant in edible oil (the response variables were the peroxide value (PV) and the conjugated dienes (CD)). It was observed that the fraction IV showed a good performance in preventing the formation of peroxides, while the best crude extract inhibited the degradation of conjugated dienes. The guava seeds are a promising source of antioxidants which can be extracted using $\mathrm{SC} \mathrm{CO}_{2} / \mathrm{EtOH}$ by special extraction step design, these compounds can be used as preservatives in foods such as edible oils.

Keywords: guava seeds, Psidium guajava L., supercritical fluid extraction, antioxidant activity, canola oil

\section{Introduction}

Guava (Psidium guajava L., Myrtaceae) is a fruit widely distributed in the tropical countries, especially in America,

*e-mail: fparadaa@unal.edu.co
Asia and Africa. In Colombia, the guava production is very important for its economy (more than $110000 \mathrm{t}$ per year were produced in 2007), ${ }^{1}$ grown in the country about 14 different varieties of this fruit, some originating in the country. The guava fruit is appreciated by high nutritional value (source of ascorbic acid and fiber) ${ }^{2,3}$ and medicinal 
properties. ${ }^{4.5}$ In the case of seeds, recently, it was evaluated the total phenolic content (TPC) and the antioxidant activity (AA) of methanolic extracts obtained from them. ${ }^{6,7}$ It has also been revealed the presence of compounds with cytotoxic activity. ${ }^{8}$ Moreover, our group has obtained edible oil and phenolic antioxidants from the seeds using supercritical $\mathrm{CO}_{2}\left(\mathrm{SC} \mathrm{CO}_{2}\right)$ pure, added with cosolvents. ${ }^{9-11}$

Among the extraction methods that have been developed in recent decades, the supercritical fluid extraction (SFE) has gained increasing acceptance, it has let development of analytical and industrial applications. ${ }^{12}$ This technique has a wide variety of benefits as that it takes advantage of the characteristics of the supercritical fluids (SF). One of the most commonly used fluid is carbon dioxide $\left(\mathrm{CO}_{2}\right)$, because it has features that make it very useful in obtaining extracts from different types of samples. The most important characteristics of $\mathrm{CO}_{2}$ are the critical conditions $\left(\mathrm{P}_{\mathrm{c}}=7.38 \mathrm{MPa}, \mathrm{T}_{\mathrm{c}}=304.1 \mathrm{~K}\right)$ suitable for thermo labile compounds, cheap and readily available, it is not toxic or flammable, under environmental conditions is a gas and it is possible to obtain solvent-free extracts. One of the disadvantages of supercritical $\mathrm{CO}_{2}$ is its low polarity which limits the extraction of some polar compounds. However, this can be overcome through various strategies, among which the most common is the use of cosolvents or also called modifiers of polarity. ${ }^{13}$ The SFE technique has a wide range of applications in areas such as cosmetics and food, among the most prominent applications are the production of decaffeinated coffee and tea, production of flavors, aromas, pigments and antioxidantes. ${ }^{12,14}$

The purpose of this study is to develop a new possibility to improve the production chain of guava, which involves an alternative use of the seeds to make full use of this fruit. Thus, phenolic extracts with antioxidant activity were obtained from guava seeds using $\mathrm{SC}_{\mathrm{CO}_{2} / \mathrm{EtOH}}$ by extraction step design. This methodology is a new way to obtain a phenolic extract with a most potent antioxidant activity from guava seeds. The extract with higher TPC and AA was subjected to flash chromatography column (FCC), finally the most active fraction and the crude extract were used as antioxidants in an edible oil.

\section{Experimental}

\section{Materials and sample preparation}

The guava seeds were obtained from the residue materials from different industries of guava jelly located at Barbosa City (Santander, Colombia). The guava seeds were washed and dried at room temperature for $24 \mathrm{~h}$ until the final moisture water content was $11.8 \%$. The samples were cold-crushed using solid $\mathrm{CO}_{2}$ and then, the guava seed particles were separated. The particle size selected for extractions was from 0.2 to $0.5 \mathrm{~mm}$. The sample was packaged in plastic bags at $278 \mathrm{~K}$ until that the extraction was performed.

The $\mathrm{CO}_{2}$ used was $99.9 \%$ of purity (Ingegas, Colombia). Ethanol, ethyl acetate, petroleum ether, propanol, chloroform, 2,2-diphenyl-1-picryl-hydrazyl (DPPH), $\beta$-carotene, 2,6-ditert-butyl-4-methyl phenol and methyl linoleate were of analytical degree (Biocol Ltda., Colombia). The solvents were distillated before the use. The silica for FCC and TLC (thin layer chromatography) was Merck.

\section{Supercritical fluid extraction unit}

For the development of this research, a homemade SFE system was used. This unit allows the extraction in static mode using $\mathrm{SC} \mathrm{CO}_{2}$ with cosolvents. The unit was formed by the following parts: $\mathrm{CO}_{2}$ reservoir, a pneumatic pump (Haskel ${ }^{\oplus}$ model AGT-7/30, CA, USA), a mixture recipient for $\mathrm{CO}_{2}$ and cosolvent, an extraction cell $(50 \mathrm{~mL})$, a separator vessel $(150 \mathrm{~mL}$ ), a thermocouple type $\mathrm{K}$ (Watlow series SD 31, MI, USA, $\pm 1 \mathrm{~K}$ ) connected to extraction cell (which was heated by a resistance) $(300 \mathrm{~W})$ and a sample collector flask. The flow was controlled by valves (Whitey series SS-1VS4 and SS-1VR4, OH, USA), being the pressure system monitored by analogical manometers (Bourdon Haenni, Vendôme cedex, France, 70 MPa). ${ }^{9}$

\section{Obtaining extracts}

As part of the results of previous research conducted by our research group, the optimal extraction conditions for obtaining phenolic extracts with antioxidant activity from guava seeds by $\mathrm{SC} \mathrm{CO}_{2} / \mathrm{EtOH}$ were 10 and $20 \mathrm{MPa}$ pressure and temperatures of 313,323 and $333 \mathrm{~K}$. Taking this as reference, it was carried out extractions with four different designs of the extraction steps (A to D). ${ }^{11,15}$ The extraction total time and the sample amount were remained constant in each design ( $2 \mathrm{~h}$ and $30.00 \mathrm{~g}$, respectively), each one of the extractions were performed by triplicate. $\mathrm{A}, \mathrm{B}$ and $\mathrm{C}$ designs were made in three extraction stages, each stage during $40 \mathrm{~min}$. The $\mathrm{D}$ design was made in six extraction stages, each stage during 20 min (Figure 1).

For each experiment, the sample was placed in the extraction cell, then the $\mathrm{SC} \mathrm{CO}_{2} / \mathrm{EtOH}$ was added at the desired extraction conditions. Finally, each one of the obtained extracts was composed of two phases, a lipidic phase (oil) and an ethanolic phase. These phases were separated by decantation and the ethanol phase was employed in various tests reported in this work. All extracts 

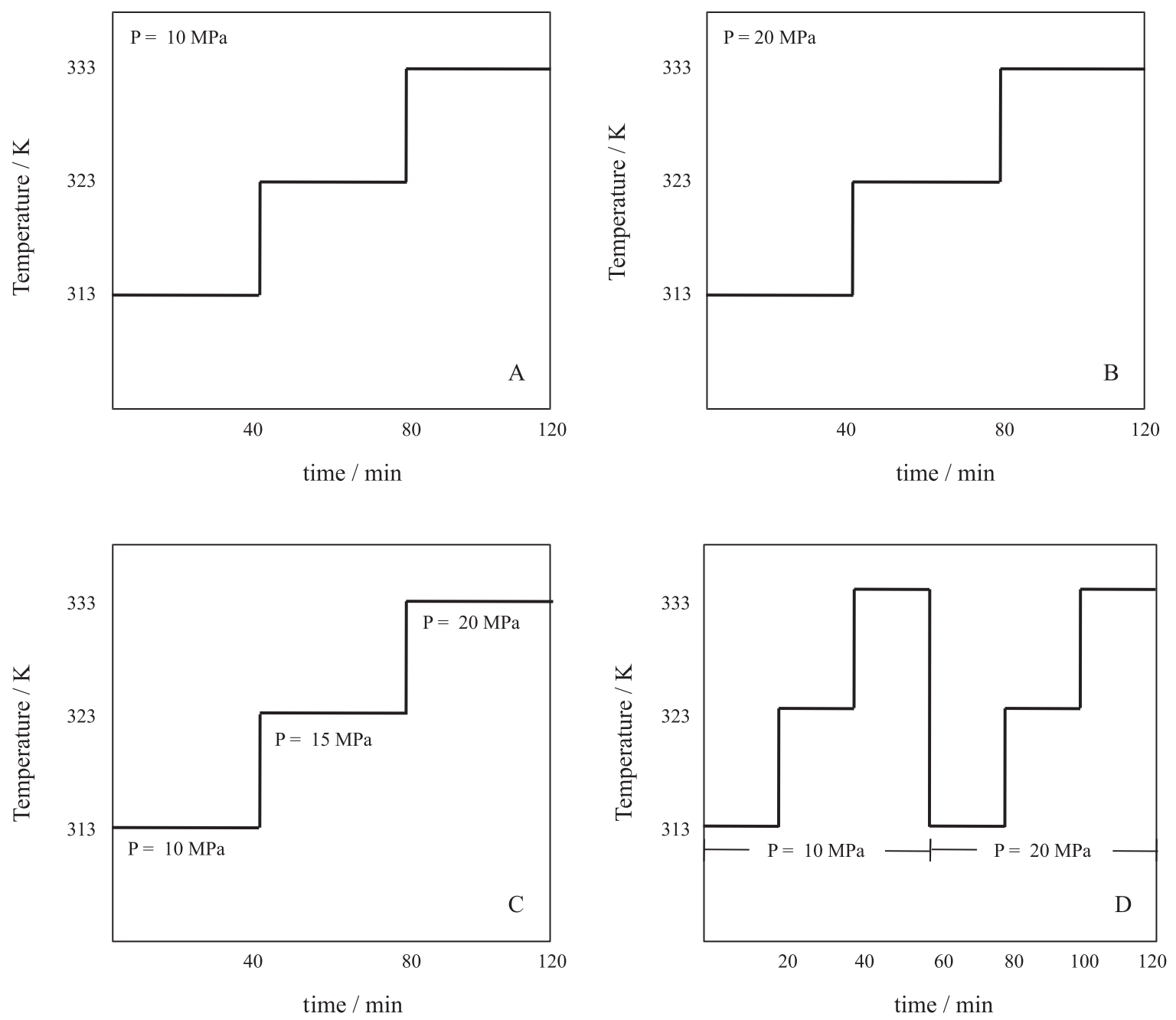

Figure 1. Extraction step design, A: three steps $(313,323,333 \mathrm{~K})$ each one at $10 \mathrm{MPa}$ for $40 \mathrm{~min}$, B: three steps $(313,323,333 \mathrm{~K})$ each one at $20 \mathrm{MPa}$ for $40 \mathrm{~min}, \mathrm{C}$ : three steps $(313 / 10,323 / 15,333 / 20 \mathrm{~K} / \mathrm{MPa})$ each one for $40 \mathrm{~min}$, D: six steps $(313 / 10,323 / 10,333 / 10,313 / 20,323 / 20,333 / 20 \mathrm{~K} / \mathrm{MPa})$ each one for $20 \mathrm{~min}$.

were concentrated to dryness using a rotary evaporator at a temperature of $313 \mathrm{~K}$ in order to evaluate the extraction yield. Then, they were reconstituted with ethanol as solvent to a final volume of $25 \mathrm{~mL}$. These extracts were used to determine TPC and AA.

\section{Flash chromatography column}

The extract with the best characteristics (extraction yield, TPC and AA) was fractionated by flash chromatography column. The amount of $550 \mathrm{mg}$ of extract (from $47.00 \mathrm{~g}$ of seeds) dissolved in ethyl acetate was placed in a glass column $(1.93 \times 60 \mathrm{~cm})$ packed with a slurry of silica gel 60 (Merck 0.046 to $0.063 \mathrm{~mm}$ ) in ethyl acetate. The mobile phase used a gradient of petroleum ether (PE) and ethyl acetate (EtAc), starting with $200 \mathrm{~mL}$ of PE, followed by $140 \mathrm{~mL}$ of PE-EtAc (9:1), $100 \mathrm{~mL}$ (8.5:1.5), $300 \mathrm{~mL}(7: 3)$ and $300 \mathrm{~mL}(1: 1)$. Each one of the solvent systems was used in the above order. The mobile phase speed was $1 \mathrm{~mL} \mathrm{~min}{ }^{-1}$, which was driven at a pressure of $c a$. $0.3 \mathrm{MPa}$. 52 sub-fractions of $20 \mathrm{~mL}$ were collected. Sub-fractions were monitored by TLC. Similar sub-fractions were joined and concentrated to a final volume of $25 \mathrm{~mL}$. These new fractions were used to determine TPC and AA.

\section{Total phenolic content (TPC)}

Total phenolic content (TPC) in the guava extracts and in the fractions were determined by the Follin-Ciocalteu method. ${ }^{11,16,17}$ A calibration curve was prepared with $50 \mu \mathrm{L}$ of gallic acid solutions $\left(0.002-0.010 \mathrm{mg} \mathrm{mL}^{-1}\right)$ in $0.5 \mathrm{~mL}$ of Follin-Ciocalteu reagent (a mixture of phosphomolybdate and phosphotungstate) and $1.5 \mathrm{~mL}$ of $\mathrm{Na}_{2} \mathrm{CO}_{3} 20 \%$. The final volume was $10.0 \mathrm{~mL}$ and was maintained in dark for $1.5 \mathrm{~h}$. The absorbance was measured 
at $760 \mathrm{~nm}$ (Thermo Electron Corp., Genesys 10-UV, CA, USA). TPC values of phenolic extracts or fractions were calculated according to calibration curve procedure and expressed as mg gallic acid in $100 \mathrm{~g}$ of guava seeds or as $\mathrm{mg}$ gallic acid in mg fraction (mg GA). ${ }^{18,19}$

\section{Antioxidant activity by $\beta$-carotene bleaching method}

The technique proposed by Miller was applied to determine the antioxidant activity by $\beta$-carotene bleaching method. ${ }^{11,20,21}$ This method is based on the reaction of $\beta$-carotene with free radicals, reducing its absorbance capacity at $470 \mathrm{~nm}$. Methyl linoleate/ $\beta$-carotene emulsion was prepared using $2.0 \mathrm{~mL}$ of $\beta$-carotene solution in chloroform $\left(1.8 \mathrm{mmol} \mathrm{L}^{-1}\right)$ and mixing with $40 \mu \mathrm{L}$ of methyl linoleate and $400 \mu \mathrm{L}$ of Tween 20 (polyoxyethylene sorbitan monolaurate). In three test tubes, the volume of 5 $\mathrm{mL}$ of emulsion was added, the first for control, the second with $50 \mu \mathrm{L}$ of 2,6-di-tert-butyl-4-methyl phenol (BHT 1.3 $\mathrm{mmol} \mathrm{L} \mathrm{L}^{-1}$ ), as the reference antioxidant compound, and the third with $50 \mu \mathrm{L}$ phenolic extract or fraction in ethanol. The tubes were incubated at $323 \mathrm{~K}$ and the absorbance at $470 \mathrm{~nm}$ was measured in 20, 40, 60, 80 and $100 \mathrm{~min}$. The antioxidant activity was calculated considering the velocity of $\beta$-carotene bleaching as control $\left(\mathrm{V}_{\mathrm{c}}\right)$ and sample $\left(\mathrm{V}_{\mathrm{a}}\right)$, according to the equation 1 :

$\mathrm{AA} \%=\frac{\mathrm{V}_{\mathrm{c}}-\mathrm{Va}}{\mathrm{V}_{\mathrm{c}}} \times 100$

\section{Antioxidant activity by DPPH scavenging method}

The DPPH radical method was based on the procedure proposed by Brand-Williams at al. ${ }^{22}$ and it was considered the modifications presented for analysis of sample containing fruit extracts. ${ }^{11,21,22}$ Briefly, it was used $2.0 \mathrm{~mL}$ DPPH solution $0.1 \mathrm{~mol} \mathrm{~L}^{-1}$ in ethanol, with absorbance measured at $517 \mathrm{~nm}\left(\mathrm{~A}_{0}\right)$. Then, $50 \mu \mathrm{L}$ of phenolic extract or fraction in ethanol were added and the absorbance measured after $1.0 \mathrm{~h}\left(\mathrm{~A}_{\mathrm{f}}\right)$. The inhibition percentage was determined as equation 2 :

inhibition $\%=\frac{\mathrm{A}_{0}-\mathrm{A}_{\mathrm{f}}}{\mathrm{A}_{0}} \times 100$

The value of inhibition \% was compared with a calibration curve prepared with Trolox (6-hydroxy-2,5,7,8tetramethylchroman-2-carboxylic acid) solutions ( 0.08 to $\left.1.24 \mathrm{mmol} \mathrm{L}^{-1}\right)$. The results are expressed in Trolox equivalent antioxidant capacity (TEAC) (mmol of Trolox in $100 \mathrm{~g}$ of guava seeds or mmol of Trolox in mg fraction). ${ }^{23-27}$

\section{Application of antioxidants in canola oil}

The antioxidant potential of the extract and of the active fraction was assessed by means of an accelerated oxidation test. These samples were added to an edible oil (canola oil) free of antioxidants in a concentration of $300 \mathrm{mg} \mathrm{kg}^{-1}$ of oil, then were homogenized and stored in an oven at $313 \pm 1 \mathrm{~K}$ for $72 \mathrm{~h}$, stirring every $2 \mathrm{~h} .{ }^{28}$ As control of the oxidation process, a sample of edible oil without additives was used, additionally, the results were compared with edible oil with BHT as reference. In both cases, the sample was initially subjected to the described process.

The degree of oil oxidation was assessed by two methods peroxide value $(\mathrm{PV})$ and conjugated diene $(\mathrm{CD})$. In the first method, $2.5 \mathrm{~g}$ of oil were subjected to oxidation and dissolved in $15 \mathrm{~mL}$ acetic acid-chloroform (3:2). Then, it was added $250 \mathrm{~mL}$ of saturated solution of potassium iodide, allowed to stand for $1 \mathrm{~min}$, followed by the addition of $15 \mathrm{~mL}$ of distilled water and titrated of the formed iodine using $0.0100 \mathrm{~mol} \mathrm{~L}^{-1}$ sodium thiosulfate with starch as an indicator. The results were expressed as milliequivalents of peroxide formed per kilogram of oil (mequiv. $\mathrm{kg}^{-1}$ ). To the determination of conjugated dienes, $40 \mu \mathrm{L}$ of oil added with sample were subjected to oxidation. Then, it was completed to a final volume of $10 \mathrm{~mL}$ with 2-propanol and the absorbance was measure at $234 \mathrm{~nm}\left(\mathrm{~A}_{\mathrm{s}}\right)$. This absorbance was compared with the control absorbance $\left(\mathrm{A}_{\mathrm{c}}\right)$, determining the percentage of inhibition as equation 3 for each one of the samples and for the BHT.

inhibition $\%=\frac{A_{c}-A_{S}}{A_{c}} \times 100$

\section{Statistic analysis}

An analysis of variances (ANOVA) for each experiment (extraction yield and quality evaluation) was carried out with the purpose of determining significant differences between the treatments carried out. Results are reported with corresponding standard deviations $( \pm \mathrm{SD})$, which were obtained from three measurements. The assays were performed in triplicate.

\section{Results and Discussion}

\section{Obtaining and analysis of the extracts}

Table 1 shows results for the extracts that were obtained (extraction yields, TPC, AA \% and TEAC). In relation to the different designs of extraction, the most efficiency 
was obtained with the design $\mathrm{D}(1157 \pm 6 \mathrm{mg}$ of phenolic extract $/ 100 \mathrm{~g}$ seeds, $1.16 \pm 0.02 \%$ ), followed by design C $(1.03 \pm 0.02 \%)$, the lowest yield corresponded to design B $(0.65 \pm 0.01 \%)$. All data were shown to be statistically different. The TPC values ranged from $112.60 \pm 21.52$ (design B) to $166.03 \pm 14.36 \mathrm{mg} \mathrm{GA} / 100 \mathrm{~g}$ seeds (design C). It was noted that the results for designs $\mathrm{A}, \mathrm{B}$ and $\mathrm{D}$ are very close. The corresponding ANOVA indicates no significant difference between them, but it is identified a significant difference between them (designs A, B and D) and the design $C$. This is because in this design, pressure and temperature changes, and these changes produce an extract phase with the most variable selectivity that can produce extracts enriched in phenolic compounds.

By comparing the obtained results for TPC against those reported in the literature, the extracts obtained in this study have a higher TPC compared with those reported for methanolic extracts obtained from Taiwan guava seeds $(40.8 \pm 1.07 \mathrm{mg} \mathrm{GA} / 100 \mathrm{~g}$ seeds $),{ }^{7}$ ethanolic extracts of Mexican chili seeds (Jalisco $92.11 \pm 0.040$ and Sinaloa $88.00 \pm 0.008 \mathrm{mg} \mathrm{GA} / 100 \mathrm{~g}$ seeds $),{ }^{29}$ methanolic and ethanolic extracts of Inga $(40.0 \pm 0.0 \mathrm{mg} \mathrm{GA}),{ }^{30}$ as well as ethanolic extracts of longan, jack, avocado and tamarind $(62.6 \pm 3.2,27.7 \pm 3.4,88.2 \pm 2.2$ and $94.5 \pm 4.9 \mathrm{mg} \mathrm{GA}$, respectively)..$^{19}$ On the other hands, TPC for our samples are less than the value reported for other seed extracts from Colombian fruits (arazá $1624 \pm 44.9$, cashew $4851 \pm 105$ and coastal zapote $1660 \pm 10.8 \mathrm{mg} \mathrm{GA}) .{ }^{31}$ It should be noted that previous studies were carried out using traditional extraction methods. Finally, TPC of extract from tamarind seeds $(166.9 \pm 6.9 \mathrm{mg} \mathrm{GA})$ obtained by $\mathrm{SC} \mathrm{CO}_{2} / \mathrm{EtOH}$ ( $353 \mathrm{~K}$ and $30 \mathrm{MPa}$ ) was comparable to that value obtained in this study by design $\mathrm{C} .^{32}$

The ability to inhibit the $\beta$-carotene discoloration by obtained extracts ranged from $70.22 \pm 0.6$ (design $\mathrm{C}$ ) to $88.72 \pm 8.23$ AA \% (design D). It is noteworthy that the extract obtained using the design $\mathrm{D}$ presented a AA \%greater than that observed for BHT $(82.17 \pm 1.25$ AA \%). The ANOVA indicated that the pair of the best extracts (B and D) did not statistically show differences.

In relation to the scavenging of DPPH, TEAC of the extracts ranged from $68.40 \pm 12.67$ (design A) to
$149.45 \pm 8.31 \mathrm{mmol}$ Trolox/100 g seeds (design D). The respective ANOVA indicated no significant difference between designs $\mathrm{A}$ and $\mathrm{B}$, and between designs $\mathrm{C}$ and $\mathrm{D}$ (these two last had the highest DPPH scavenging), but it indicated significant differences between the pairs $\mathrm{AB}$ and CD. By comparing results for the DPPH scavenging with those reported in the literature, it appears that extracts from guava seeds have a higher DPPH scavenging than the reported for methanolic extract obtained from tamarindo seeds $\left(39.0 \pm 0.05 \mathrm{mmol}\right.$ Trolox $/ 100 \mathrm{~g}$ seeds). ${ }^{33}$

By comparing the results for yield (TPC and AA (AA \%, TEAC)) against the previous guava seeds reported by our research group, in the present work by design $\mathrm{D}$ extraction, it was possible a better yield $(1.16 \pm 0.02 \%)$ with $115.99 \pm 7.10 \mathrm{mg} \mathrm{GA} / 100 \mathrm{~g}$ seeds as TPC, AA \% of $88.72 \pm 8.23 \%$ and TEAC of $149.45 \pm 8.31 \mathrm{mmol}$ Trolox/100 g seeds. These results contrast with results obtained in a recent work that used the parameters $333 \mathrm{~K}$ and $10 \mathrm{MPa}{ }^{11}$ In this one, the yield of guava seed extract was $0.77 \pm 0.01 \%$, TPC $153 \pm 1.0 \mathrm{mg} \mathrm{GA} / 100 \mathrm{~g}$ seeds, AA $\% 48.9 \pm 4.91$ and TEAC $136 \pm 3.0 \mathrm{mmol}$ Trolox $/ 100 \mathrm{~g}$ seeds. ${ }^{11}$ The coefficient between TEAC/TPC showed the selectivity potential of the new extraction method (design D), because by this methodology, the phenolic fraction has a high AA potential (TEAC/TPC $1.29 \mathrm{mmol}$ Trolox/mg GA) than the previous methodology ( $333 \mathrm{~K}$ and $10 \mathrm{MPa}$, TEAC/TPC was $0.89 \mathrm{mmol}$ Trolox $/ \mathrm{mg} \mathrm{GA}$ ), see Table $1 .{ }^{11}$ On the other hand, those values permitted to observe that in phenolic extract from guava seeds there were most antioxidant activity than other vegetal material (e.g., in the methanolic extract from Averrhoa carambola residues, TEAC/TPC was $0.06 \mathrm{mmol}$ Trolox/mg GA). ${ }^{34}$

The extract obtained corresponding to the design D presented the best characteristics in relation to the extraction yield and AA. Through this design, it was possible to obtain extracts with the highest AA \% and TEAC, but its TPC was not the greatest, even though it remained within the overall average among all designs. It was considered that the extract obtained using the design D had the best features (extraction yield, TPC, AA and TEAC/TPC), so that this extract was selected for fractionation using FCC.

Table 1. Extraction yield, total phenolic content and antioxidant activity from obtained extracts

\begin{tabular}{lccccc}
\hline Extract & Yield / & $\begin{array}{c}\text { TPC/ } \\
\text { (mg GA/100 g seeds) }\end{array}$ & $\begin{array}{c}\text { AA/ } \\
\%\end{array}$ & $\begin{array}{c}\text { TEAC/ } \\
\text { (mmol Trolox/100 g seeds) }\end{array}$ & $\begin{array}{c}\text { TEAC/TPC } \\
(\mathrm{mmol} \text { Trolox/mg GA) }\end{array}$ \\
\hline Design A & $0.74 \pm 0.02$ & $120.99 \pm 10.85$ & $77.67 \pm 10.90$ & $68.40 \pm 12.67$ & 0.57 \\
Design B & $0.65 \pm 0.01$ & $112.60 \pm 21.52$ & $80.99 \pm 0.80$ & $89.11 \pm 8.15$ & 0.79 \\
Design C & $1.03 \pm 0.02$ & $166.03 \pm 14.36$ & $70.22 \pm 0.62$ & $136.82 \pm 14.54$ & 0.82 \\
Design D & $1.16 \pm 0.02$ & $115.99 \pm 7.10$ & $88.72 \pm 8.23$ & $149.45 \pm 8.31$ & 1.29 \\
\hline
\end{tabular}




\section{Fractionation and analysis of the fractions}

By FCC, it was possible to collect 52 sub-fractions following the methodology previously described. The crude extract and each sub-fraction were checked by TLC in order to associate the components that were detected in each sub-fraction with signals that were observed in the crude extract. By the TLC of the crude extract, five signals were observed and were correlated with the FCC collected sub-fractions. The 17 to 20 sub-fractions were the fraction I $\left(\mathrm{R}_{\mathrm{f}}\right.$ between 0.94 and $\left.0.95,48 \pm 1.0 \mathrm{mg}\right)$, the fraction II was composed of 26 to 28 sub-fractions $\left(\mathrm{R}_{\mathrm{f}} 0.70\right.$ to 0.72 , $49 \pm 1.6 \mathrm{mg}$ ), 29 to 31 sub-fractions were collected in fraction III ( $\mathrm{R}_{\mathrm{f}} 0.57$ to $\left.0.64,64 \pm 2.8 \mathrm{mg}\right)$, and finally 39 to 43 sub-fractions were the fraction IV $\left(R_{\mathrm{f}} 0.50\right.$ to $0.52,75 \pm 2.9 \mathrm{mg}$ ). Table 2 summarizes the results for the new four fractions (TLC monitoring, TPC, $\beta$-carotene bleaching, scavenging DPPH and TEAC/TPC).

The fraction IV showed the highest values in each one of the evaluated variables $(75 \pm 2.9 \mathrm{mg}$ of fraction, $0.20 \pm 0.02 \mathrm{mg} \mathrm{GA} / \mathrm{mg}$ fraction, $56.84 \pm 1.33 \% \mathrm{AA}$ and $0.10 \pm 0.02 \mathrm{mmol}$ Trolox $/ \mathrm{mg}$ fraction). Particularly, AA called more attention for the research, indicating that this fraction could have the greatest efficiency when applied as an antioxidant in edible oil exposed to oxidative degradation. Another aspect to note from the new four fractions obtained is that the most active fraction has the compounds with higher polarity, probably including polyphenols, explaining the higher TPC and AA compared to the other fractions. However AA of the design D extract $(88.72 \pm 8.23 \mathrm{AA} \%, 0.13 \mathrm{mmol}$ Trolox/mg extract) was better than AA of the fraction IV $(56.84 \pm 1.33 \mathrm{AA} \%$, $0.10 \mathrm{mmol}$ Trolox/mg fraction), these results suggest that in the extract there are synergic effects. In this way, the TEAC/TPC factor measures the potential of antioxidant activity of phenolic compounds that are contained in each fraction or in each extract, e.g., the fraction IV has a
TEAC/TPC factor of $0.50 v s$. design D extract that has a TEAC/TPC factor of 1.29 , this indicates that there is a synergistic effect in the extract.

Then, the design D extract could be used as a substitute of synthetic antioxidants. The fraction IV and design D extract were chosen to implement the accelerated oxidation test in edible oil.

Application of extracts and fractions to an edible oil antioxidant

The extract obtained using the design $\mathrm{D}$ and the fraction IV from FCC were used as antioxidants in edible oil subjected to accelerated oxidation, comparing with BHT as antioxidant reference. Figure 2 presents results for the evaluated variables (PV and $\mathrm{CD}$ ).

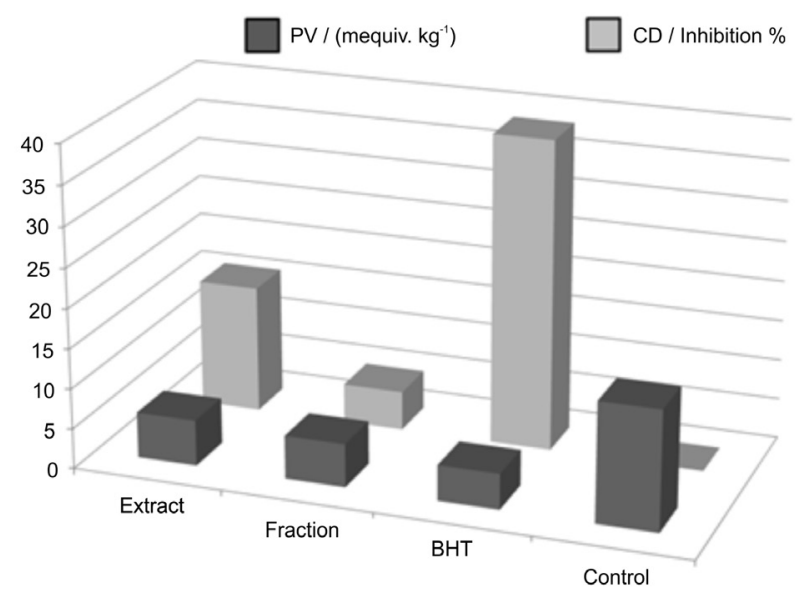

Figure 2. Peroxide value-PV and conjugated dienes-CD observed in the quick oxidation assay. Design D extract, fraction IV, BHT, control.

PV values for three antioxidants showed very close values (design D extract $5.72 \pm 0.10$, fraction IV $5.40 \pm 1.45$, BHT $4.45 \pm 1.10) v s$. control $\left(14.94 \pm 4.80\right.$ mequiv. $\mathrm{kg}^{-1}$ of oil), suggesting that any of three can be employed in

Table 2. Obtained fractions by FCC from design D extract

\begin{tabular}{|c|c|c|c|c|c|c|}
\hline Fraction & $\begin{array}{c}\text { Sub-fractions } \\
\left(\mathrm{R}_{\mathrm{f}}\right)\end{array}$ & mass / mg & $\begin{array}{c}\text { TPC } \\
\text { (mg GA/mg fraction) }\end{array}$ & AA $/ \%$ & $\begin{array}{c}\text { TEAC } \\
\text { (mmol Trolox/mg fraction) }\end{array}$ & $\begin{array}{c}\text { TEAC/TPC } \\
(\mathrm{mmol} \text { Trolox/mg GA) }\end{array}$ \\
\hline I & $\begin{array}{c}17-20 \\
(0.94-0.95)\end{array}$ & $48 \pm 1.0$ & $0.18 \pm 0.08$ & $33.61 \pm 2.86$ & $0.06 \pm 0.06$ & 0.35 \\
\hline II & $\begin{array}{c}26-28 \\
(0.70-0.72)\end{array}$ & $49 \pm 1.6$ & $0.16 \pm 0.02$ & $49.53 \pm 0.42$ & $0.08 \pm 0.009$ & 0.53 \\
\hline III & $\begin{array}{c}29-31 \\
(0.57-0.64)\end{array}$ & $64 \pm 2.8$ & $0.15 \pm 0.004$ & $37.25 \pm 0.78$ & $0.05 \pm 0.01$ & 0.35 \\
\hline IV & $\begin{array}{c}39-43 \\
(0.50-0.52)\end{array}$ & $75 \pm 2.9$ & $0.20 \pm 0.02$ & $56.84 \pm 1.33$ & $0.10 \pm 0.02$ & 0.50 \\
\hline \multicolumn{2}{|c|}{ Design D extract } & $347 \pm 6.10$ & $\begin{array}{c}0.10 \pm 0.01 \\
\mathrm{mg} \mathrm{GA} / \mathrm{mg} \text { extract }\end{array}$ & $88.72 \pm 8.23$ & $\begin{array}{c}0.13 \pm 0.01 \\
\mathrm{mmol} \text { Trolox/mg extract }\end{array}$ & 1.29 \\
\hline
\end{tabular}


preventing the formation of peroxides in an oil edible subjected to oxidation. $\mathrm{CD}$ values showed that the extract obtained using the design $\mathrm{D}$ can be used as an edible oil antioxidant exposed to oxidative degradation (Inhibition $\%=15.86 \pm 0.14 \%$ ), with a potential less than that for the BHT (Inhibition $\%=38.67 \pm 4.42 \%$ ).

\section{Conclusions}

By supercritical fluid extraction (SFE) (using $\mathrm{SC} \mathrm{CO}_{2} / \mathrm{EtOH}$ ), it was was accomplished the production of phenolic extracts with antioxidant activity from Colombian guava seeds, the best extraction design was made by a batch with six extraction steps, each one of $20 \mathrm{~min}$, namely $313 / 10$, $323 / 10,333 / 10,313 / 20,323 / 20$ and 333/20 K/MPa (designD). This extract presented the best yield $(1.16 \pm 0.01 \%)$, the higher antioxidant activity $(88.72 \pm 8.23$ AA $\%$, $149.45 \pm 8.31 \mathrm{mmol}$ Trolox/100 g seeds), the new procedure permitted to obtain the phenolic fraction with most antioxidant activity (1.29 mmol Trolox/mg GA), with more selectivity. The extract obtained by design D can be employed in preventing the formation of peroxides in an oil edible subjected to oxidation and the $\mathrm{CD}$ value showed that this extract can be used as an edible oil antioxidant exposed to oxidative degradation, it had a potential slightly less than that for the synthetic antioxidant usually used in the food industry. This extract was fractionated using flash chromatography column, obtaining four fractions and fraction IV was the highest antioxidant activity and a good potential in the prevention of peroxide formation in edible oil, opening the possibility of substituting artificial antioxidants by natural antioxidants.

The development of this research allows to demonstrate that the guava seeds can be considered as a promising source of antioxidants, which may be used in different fields (such as food, pharmaceutical and cosmetics, among others). It also raises a new possibility for the use of this agro-industrial waste, which opens possibilities for the use of the whole fruit, providing an added value within their supply chain.

\section{Acknowledgments}

The authors thank Ministry of Agriculture and Rural Development of Colombia (project No. 20301008343) and Universidad Nacional de Colombia (project No. 20601002526).

\section{References}

1. Ministry of Agriculture and Rural Development of Colombia, Colombian Corporation of Agriculture Investigation CORPOICA-
CIMPA; La Agroindustria de la Guayaba, en la Provincia de Vélez Departamento de Santander (Colombia); Ministry of Agriculture and Rural Development of Colombia: Bogotá, 2007.

2. Jiménez, A.; Rincón, M.; Pulido, R.; Saura-Calixto, F.; J. Agric. Food Chem. 2001, 49, 5489.

3. Martínez, M; Ortíz-Quintero, B. L.; Pérez-Gualdrón, C. E.; Anzola-Velazco, C.; Rev. Fac. Med. 2011, 59, 103.

4. Lozoya, X.; Reyes, H.; Chávez, M.; Martínez, C.; Soto, Y.; J. Ethnopharmacol. 2002, 83, 19.

5. Abdelrahim, S. I.; Almagboul, A. Z.; Omer, M.; Elegamib, A.; Fitoterapia 2002, 73, 713.

6. Guo, G.; Yang, J.; Wei, J.; Li, Y.; Xu, J.; Jiang, Y.; Nutr. Res. 2003, 23, 1719.

7. Huang, H.; Chang, C.; Tso, T.; Huang, J.; Chang, W.; Tsai, Y.; Int. J. Food Sci. Nutr. 2004, 55, 423.

8. Salib, Y.; Michael, H.; Phytochemistry 2004, 65, 2091.

9. Castro-Vargas, H. I.; Rodríguez-Varela, L. I.; Parada-Alfonso, F.; J. Supercrit. Fluids 2011, 56, 238.

10. Nivia, A.; Castro, H.; Parada, F.; Rodríguez, I.; Restrepo, P.; Sci. Tech. 2007, 33, 79. http://www.utp.edu.co/php/revistas/ ScientiaEtTechnica/docsFTP/10145579-82.pdf (in Spanish)

11. Castro, H. I.; Rodríguez, L. I.; Ferreira, S.; Parada, F.; J. Supercrit. Fluids 2010, 51, 319.

12. Brunner, G.; J. Food Eng. 2005, 67, 21.

13. Luque de Castro, M. D.; Tena, M. T.; TrAC, Trends Anal. Chem. 1996, 15, 32.

14. Chester, T. L.; Pinkston, J. D.; Raynie, D. E.; Anal. Chem. 1996, 68, 487R.

15. Gaitán, S.; Solano, A.; Restrepo, P.; Rodríguez, I.; Parada, F.; Actual. Biol. 2005, 27, 59.

16. Folin, O.; Ciocalteu, V.; J. Biol. Chem. 1927, 73, 627.

17. Magalhães, L.; Segundo, M.; Reis, S.; Lima, J.; Rangel, A.; J. Agric. Food Chem. 2006, 54, 5241.

18. Kitzberger, C.; Smânia, A. Jr.; Pedrosa, R. C.; Ferreira, S. R. S.; J. Food Eng. 2007, 80, 631.

19. Soong, Y.; Barlow, P. J.; Food Chem. 2004, 88, 411.

20. Miller, H.; J. Am. Oil Chem. Soc. 1971, 45, 91.

21. Lu, Y.; Foo, L.; Food Chem. 2000, 68, 81.

22. Brand-Williams, W.; Cuvelier, M.; Berset, C.; Lebensm. Wiss. Technol. 1995, 22, 25.

23. Kuskoski, M.; Asuero, A.; Troncoso, A. Mancini-Filho, J.; Fett, R.; Ciênc. Tecnol. Aliment. 2005, 25, 726.

24. Krings, U.; Berger, R.; Food Chem. 2001, 72, 223.

25. Furiga, A.; Lonvaud-Funel, A.; Badet, C.; Food Chem. 2009, 113, 1037.

26. Bail, S.; Stuebiger, G.; Krist, S.; Unterweger, H.; Buchbauer, G.; Food Chem. 2008, 108, 1122.

27. Thaipong, K.; Boonprakob, U.; Crosby, K.; Cisneros-Zevallos, L.; Byrne, D.; J. Food Comp. Anal. 2006, 19, 669.

28. Wanasundara, U.; Fereidoon, S.; Food Chem. 1996, 44, 1687. 
29. Reyes-Caudillo, E.; Tecante, A.; Valdivia-López, M.; Food Chem. 2008, 107, 656.

30. Silva, E.; Souza, J.; Rogez, H.; Rees, J.; Larondelle, Y.; Food Chem. 2007, 101, 1012.

31. Contreras-Calderón, J.; Calderón-Jaimes, L.; Guerra-Hernández, E.; García-Villanova, B.; Food Res. Int. 2011, 44, 2047.
32. Tsuda, T.; Mizuno, K.; Ohshima, K.; Kawakishi, S.; Osawa, T.; J. Agric. Food Chem. 1995, 43, 2803.

33. Siddhuraju, P.; LWT Food Sci. Technol. 2007, 40, 982.

34. Shui, G.; Leong, L. P.; Food Chem. 2006, 97, 277.

Submitted: August 19, 2011 Published online: December 6, 2011 